\title{
Pengembangan Kontrol Alat Elektronik Pada SMK XYZ
}

\author{
Chrisyantus Leto \\ Program Studi Teknik Informatika \\ Universitas Tribuana Kalabahi \\ Welai Teim., Tlk. Mutiara, Alor, Nusa Tenggara Timur \\ chrisyantusleto@gmail.com
}

\author{
Julminggu Selly \\ Program Studi Teknik Informatika \\ Universitas Tribuana Kalabahi \\ Welai Teim., Tlk. Mutiara, Alor, Nusa Tenggara Timur \\ chrisyantusleto@gmail.com
}

\begin{abstract}
Abstrak - Tujuan dari penulisan skripsi adalah untuk menghasilakan karya nyata mengotrol suatu alat elektronik secara sistem otomatis agar mempermudah manusia dalam melakukan pekerjaanya dalam keadaan jarak jauh. Metode Penelitian yang digunakan adalah dengan metode pengumpulan data dan pengembangan sistem (Prototype). Dimana penulis mengumpulkan data yang dibutuhkan serta mendengarkan permintaan pengguna kemudian membangun Prototype itu.Hasil yang dicapai adalah menyalakan dan mematikan suatu alat elektronik dengan menggunakan Visual Basic 2010 yang dihubungkan dengan Device Controller. Dengan ini mempermudah kerja manusia dalam mengontrol alat elektronik tersebut pada jarak jauh.Kesimpulan bahwa Pengembangan Kontrol Alat Elektronik Menggunakan Visual Basic 2010 pada SMK XYZ jarak jauh menggunakan Visual Basic 2010 dapat di hubungkan dengan Device Controller yang terhubung dengan alat elektronik dan dapat mengontrol secara jarak jauh.
\end{abstract}

Kata Kunci- Sistem Otomatis, Alat Kontrol, Alat Elektronik, Pengembangan.

\section{PENDAHULUAN}

Perkembangan ilmu pengetahuan dan teknologi (IPTEK) dewasa ini sangat pesat, terutama di bidang teknologi elektronika dan komputer mengakibatkan beberapa efek yang mempengaruhi kehidupan masyarakat untuk melangkah lebih maju (modernisasi), berfikiran praktis dan simple. Hal semacam ini memerlukan sarana pendukung yang sederhana, praktis dan berteknologi tinggi. Hal ini dapat disaksikan bahwa pembuatan peralatan-peralatan yang serba otomatis yang mengesampingkan peran manusia sebagai subjek pekerjaan telah banyak ditemukan. Untuk memenuhi kebutuhan otomatisasi ini diperlukan peralatan kontrol yang bisa memenuhi kebutuhan tersebut. Alat-alat kontrol ini diantaranya alat kontrol berbasis mikrokontroler, saklar-saklar otomatis, dan pemprograman visual.
Pemakaian Pemprograman visual sebagai alat kontrol untuk beberapa sistem otomatisasi telah banyak digunakan karena Pemprograman visual dapat diberi perintah masukan yang memungkinkan dapat diterapkan dalam sistem pengoperasian alat elektronik secara otomatis. Pada sistem ini kontrol alat elektronik akan on/off sendiri ketika mengklik perintah di komputer yang akan on/off dan proses ini akan berulang-ulang secara otomatis.

Keterbatasan sumber daya manusia dalam melakukan suatu pekerjaan dalam mempergunakan peralatan elektronik sehingga terjadinya proses pemborosan terhadap pemakaian tenaga listrik di SMK XYZ .

Alat eletronika ini akan bekerja apabila terhubung baik dengan visual basic 2010. Disini saya akan lebih memperjelas kepada software yang digunakan. Suatu alat pengendali eletronik dapat bekerja apabila terhubung dengan baik dengan software yang di gunakan.

\section{LANDASAN TEORI}

Landasan teori/ tinjauan pustaka yang akan menjadi acuan dalam penelitian ini adalah sebagai berikut :

\section{A. Sistem Kendali}

Sistem kendali atau sistem kontrol (control system) adalah suatu alat (kumpulan alat) untuk mengendalikan, memerintah, dan mengatur keadaan dari suatu sistem. Istilah sistem kendali ini dapat dipraktekkan secara manual untuk mengendalikan stir mobil pada saat kita mengendarai/menyetir mobil kita, misalnya, dengan menggunakan prinsip unpan balik. Dalam sistem yang otomatis, alat semacam ini sering dipakai untuk peluru kendali sehingga peluru akan mencapai sasaran yang diinginkan. Banyak contoh lain dalam bidang industri / instrumentasi dan dalam kehidupan kita sehari-hari di mana sistem ini dipakai. Alat pendingin (AC) merupakan contoh yang banyak kita jumpai yang menggunakan prinsip sistem kendali, karena suhu ruangan dapat dikendalikan sehingga ruangan berada pada suhu yang kita inginkan. (Wikipedia). 


\section{B. Visual Basic}

Visual Basic merupakan bahasa pemprograman yang cukup populer dan mudah untuk dipelajari. Visual Basic juga menyediakan fasilitas yang memungkinkan pemakai menyusun sebuah program dengan memasang objek-ojek grafis dalam sebuah grafis dalam sebuah form. ( Menurut Wahyu Nurdila Riantiningsih dalam Tugas Akhir Pulikasi 2009).

Visual Basic 2010 merupakan versi Visual Basic yang dikeluarkan oleh Microsoft pada tahun 2010. Versi ini hampir serupa dengan versi Visual Basic 2008 dengan penambahan beberapa vitur baru. Pemrograman Visual Basic telah melalui beberapa fase pengembangan sejak pertama kali dikeluarkan BASIC (Beginners All-purpose Symbolic Instruction Code) pada versi DOS. Microsoft meluncurkan Visual Basic versi 1.0 pada tahun 1991 dan perlahan Microsoft merubah semua versi DOS menjadi MS Windows yang dikenal dengan Visual Basic. ( Menurut Weldan Kusuf :06:2013).

\section{Mikrokontroller AVR}

AVR merupakan salah satu jenis mikrokontroler yang dibuat oleh Atmel Corp. AVR ini berupa chip atau IC (Integrated circuit) yang dapat di program karena didalamnya telah tertanam mikroprosesor, perangkat penyimpanan (memori) dan beberapa modul I/O layaknya sebuah komputer yang siap pakai.

Meskipun AVR serupa dengan komputer, tetap terdapat perbedaan-perbedaan diantara keduanya. Jika komputer dirancang untuk menyelesaikan banyak tugas (multitasking), maka mikrokontroler dibuat sebaliknya, yaitu untuk mengerjakan suatu tugas tertentu dan spesifik.

\section{Resitor}

Resistor merupakan salah satu komponen yang paling sering ditemukan dalam Rangkaian Elektronika. Hampir setiap peralatan Elektronika menggunakannya. Pada dasarnya Resistor adalah komponen Elektronika Pasif yang memiliki nilai resistansi atau hambatan tertentu yang berfungsi untuk membatasi dan mengatur arus listrik dalam suatu rangkaian Elektronika. Resistor atau dalam bahasa Indonesia sering disebut dengan Hambatan atau Tahanan dan biasanya disingkat dengan Huruf "R". Satuan Hambatan atau Resistansi Resistor adalah OHM $(\Omega)$. Sebutan "OHM" ini diambil dari nama penemunya yaitu George Simon Ohm yang juga merupakan seorang Fisikawan Jerman.

\section{E. Dioda}

Pengertian dioda adalah komponen elektronika yang terdiri dari dua elektroda, yakni anoda dan katoda. Kata "dioda" adalah sebuah kata majemuk yang berarti "dua elektroda", dimana "di" berarti dua dan "oda" yang berarti elektroda. Jadi dioda adalah dua lapisan elektroda $\mathrm{N}$ (katoda) dan lapisan P (anoda), dimana $\mathrm{N}$ berarti negatif dan $\mathrm{P}$ adalah positif.

Dioda merupakan komponen yang paling sederhana pada keluarga semikonduktor. Bentuk dioda ini sejenis vacuum tube yang memiliki dua buah elektroda yang terbuat dari bahan semikonduktor.

\section{F. Transistor}

Transistor adalah komponen semikonduktor. Fungsi transistor yakni sebagai penguat, sebagai pemutus dan penyambung (saklar), stabilisasi tegangan, modulasi sinyal dan bebagai fungsi lainnya. Transistor pun dapat berfungsi semacam kran listrik, dimana berdasarkan arus inputnya Basic Junktion Transistor (BJT) atau tegangan inputnya Field Effect Transistor (FET), memungkinkan pengaliran listrik yang sangat akurat dari sirkuit sumber listriknya.

\section{G. LED (Light Emiting Diode)}

LED atau singkatan dari Light Emitting Diode adalah salah satu komponen elektronik yang tidak asing lagi di kehidupan manusia saat ini. LED saat ini sudah banyak dipakai, seperti untuk penggunaan lampu permainan anak-anak, untuk ramburambu lalu lintas, lampu indikator peralatan elektronik hingga ke industri, untuk lampu emergency, untuk televisi, komputer, pengeras suara (speaker), hard disk eksternal, proyektor, LCD, dan berbagai perangkat elektronik lainnya sebagai indikator bahwa sistem sedang berada dalam proses kerja, dan biasanya berwarna merah atau kuning. LED ini banyak digunakan karena komsumsi daya yang dibutuhkan tidak terlalu besar dan beragam warna yang ada dapat memperjelas bentuk atau huruf yang akan ditampilkan. dan banyak lagi.

Pada dasarnya LED itu merupakan komponen elektronika yang terbuat dari bahan semi konduktor jenis dioda yang mampu memencarkan cahaya. LED merupakan produk temuan lain setelah dioda. Strukturnya juga sama dengan dioda, tetapi belakangan ditemukan bahwa elektron yang menerjang sambungan P-N. Untuk mendapatkna emisi cahaya pada semikonduktor, doping yang pakai adalah galium, arsenic dan phosporus. Jenis doping yang berbeda menghasilkan warna cahaya yang berbeda pula.

\section{PEMOdelan PRoYeK}

\section{A. Objective Proyek}

Pelaksanaan penelitian dilakukan pada SMK XYZ menggunakan pengembangan control alat elektronik dengan menggunakan Visual basic. Dengan ada pengembangan kontrol alat elektronik dapat memudahkan pihak sekolah dalam mengatur waktu yang tepat dalam On/Off suatu alat elektronik tanpa pemborosan listrik maupun tenaga manusia.

Mikrokontroler merupakan miniatur komputer dengan teknologi baru yang banyak dikembangkan. Banyak aplikasiaplikasi baru menggunakan mikrokontroler sebagai basisnya, Atmel, salah satu perusahaan pembuat mikrokontroler terbesar, menciptakan mikrokontroler yang lebih canggih daripada generasi sebelumnya. Mikrokontroler tersebut adalah mikrokontroler jenis AVR (Advanced Virtual RISC). Dengan adanya pengembangan kontrol elektronik dengan Visual Basic 2010 nantinya diharapkan dapat menarik manfaat sebagai berikut : 
- Alat elektronik sebelumnya manual dan kurang efektif, kini lebih prakatis bila menggunakan Interface Visual Basic 2010.

- Dengan menghubungkan alat tersebut dengan Visual Basic 2010, maka alat elektronik dapat dikendalikan dengan jarak jauh.

- Membangun dan merancangan pengendali alat elektronik dengan Visual Basic 2010.

\section{B. Identifikasi Stakeholder}

Dalam pelaksanaan proyek pengembangan kontrol alat elektronik dengan Visual Basic 2010 pada SMK XYZ . Melibatkan beberapa Stakeholder yang sangat mendukung terlaksananya proyek tersebut. Dari identifikasi stakeholder maka ditetapkan stakeholder di lingkup manajemen proyek pengembangan kontrol alat elektronik dengan Visual Basic 2010 pada SMK XYZ adalah pihak sekolah itu sendiri seperti bagian:

- Kepala Sekolah

- Tata Usaha (Pengambilan Data)

\section{Identifikasi Deliverables}

Pelaksanaan pengembangan kontrol alat elektronik dengan Visual Basic 2010 pada SMK XYZ diterapkan pada 8 alat yaitu Kipas Angin, Kulkas, Televisi, Infocus, Mesin Air, Mesin Fotocopy, Ampli, dan Monitor Sound. Setiap satu tombol saklar pada form Visual Basic minimal mewakili setiap alat elektronik dan maksimal sesuai permintaan pengguna.

\section{Penjadwalan Proyek}

Dalam pelaksanaan proyek pengembangan kontrol alat elektronik dengan Visual Basic 2010 pada SMK XYZ terdapat kegiatan yang menyangkut kebutuhan pengembangan dan tergambar dalam beberapa jadwal kegiatan proyek. Jadwal kegiatan proyek tergambar sebagai berikut.

- Work Breakdown Structure

- Milestone

- Jadwal Proyek

- Rencana Anggaran Biaya

- Struktur Tim Proyek

\section{1) Work Breakdown Structure}

Pelaksanaan proyek pengembangan kontrol alat elektronik dengan Visual Basic 2010 pada SMK XYZ menggunakan WBS (Work Breakdown Structure). WBS (Work Breakdown Structure) tersebut berfungsi sebagai teknik pemecahan kegiatan menjadi bagian-bagian yang lebih kecil dan terstruktur. Berikut dibawah ini adalah gambar WBS (Work Breakdown Structure) yang digunakan dalam pelaksanaan proyek.

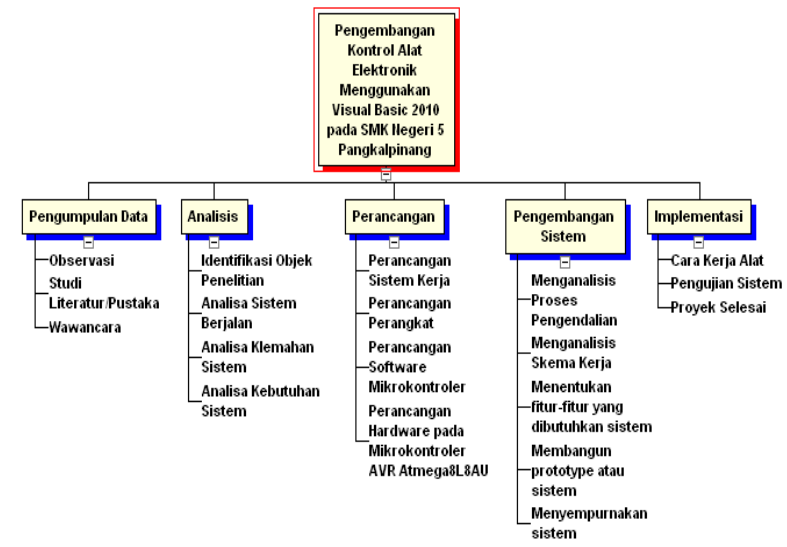

Gambar 1. Work Breakdown Structure

\section{2) Milestone}

Milestone digunakan untuk membagi pekerjaan menjadi lebih kecil sehingga mudah untuk di monitoring dan di evaluasi, berikut milestone pelaksanaan proyek prototype pengendali alat elektronik dengan Visual Basic 2010.

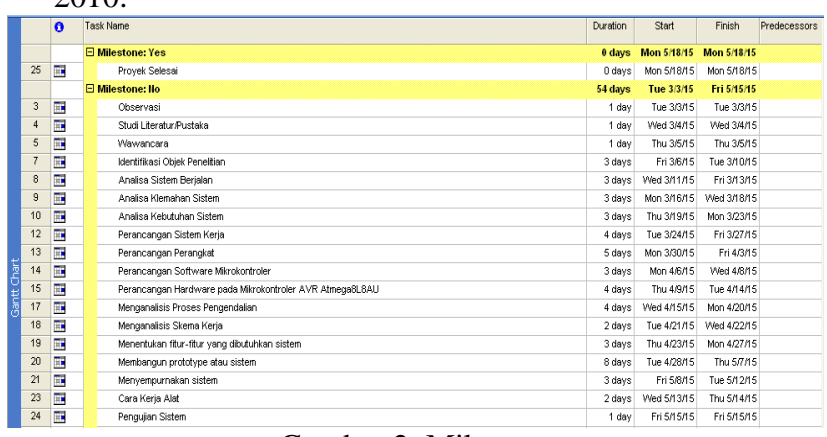

Gambar 2. Milestone

\section{ANALISA DAN PERANCANGAN}

\section{A. Analisa Masalah}

Adapun analisis masalah pada penelitian ini adalah penyajian informasi yang mengenai perancangan pengontrolan alat elektronik dengan Visual Basic 2010 sebagai sarana menyalakan dan mematikan alat elektronik.

Analisis masalah merupakan salah satu tahapan pada perancangan pengontrolan alat elektronik melalui visual basic 2010 yang sangat penting, karena kesalahan di dalam tahap ini akan menyebabkan kesalahan di tahap selanjutnya.

\section{1) Analisa Sistem Berjalan}

Terbatasnya sumber daya manusia yang ada di SMK XYZ terkadang lupa mematikan alat elektronik yang menyebabkan pemborosan terhada pemakaian listrik, infrastruktur SMK XYZ yang gedung bertingkat untuk mematikan alat elektronik yang ada di ruangan-ruangan membuat sumber daya manusia malas melakukannya. 
Sistem yang sedang berjalan saat ini di SMK XYZ adalah sistem pengontrolan manual masih memanfatkan tenaga manusia untuk mengecek setiap ruangan apakah ala-alat elektronik sudah dimatikan. Dengan kata lain, segala prosedur dan sistem yang dijalankan oleh manusia dan belum bersifat Pemrograman.

Dengan sistem pengontrolan alat elektronik menggunakan visual basic 2010, aktivitas manusia digantikan oleh sistem yang dirancang dan mempermudah pengontrolan alat elektronik tersebut di SMK XYZ. Sistem ini menggunakan mikrokontroler yang dapat dikontrol dengan visual basic 2010 secara jarak jauh, dari visual basic 2010 dihubungkan dengan mikrokontroler dengan menggunakan kabel USB dan menghubungkan ke alat elektronik

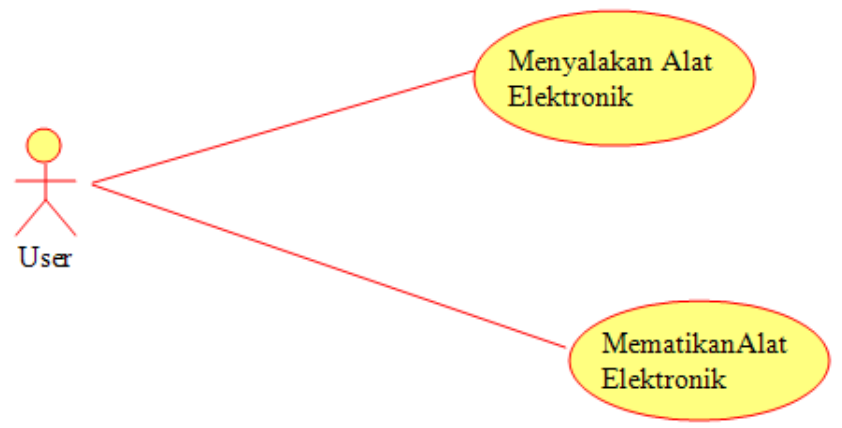

Gambar 3. Use Case Sistem Berjalan

\section{2) Jenis Penelitian}

Untuk melakukan penelitian perancangan pengontrolan alat elektronik dengan visual basic 2010 ini menggunakan jenis penelitian terapan. Dimana penelitian jenis ini bertujuan memberikan solusi dari permasalahan tertentu secara praktis. Selain itu penelitian ini bertujuan untuk menunjang kegiatan pengembangan atau penerapan suatu sistem seperti sistem pengontrolan alat elektronik dengan visual basic 2010, atau bahasa pemprograman.

\section{B. Perancangan}

Iterasi prototyping direncanakan secara cepat, demikian juga rancangan model segera dibuat. Perancangan yang cepat berfokus pada penggambaran aspek-aspek perangkat lunak yang akan dilihat oleh pengguna. Proses pengiriman perintah (On/Off) ke alat melalui Visual Basic 2010 untuk mengontrol peralatan elektronik .

- Menganalisis alur proses sistem pengendalian berupa pengiriman instruksi dari device Visual Basic 2010 ke mikrokontroler dan kemudian mengekseskusi instruksi ke peralatan listrik,

- Menganalisis skema kerja pembuatan aplikasi Visual Basic 2010,

- Menentukan fitur - fitur yang dibutuhkan pada sistem,

- Membangun prototype atau sistem,

- Menyempurnakan prototype sesuai dengan kebutuhan
Sistem kerja aplikasi pengontrol alat elektronik SMK XYZ menggunakan Visual Basic 2010 ini yaitu user memberi perintah melalui software yang terhubung dengan mikrokontroler menyampaikan ke alat elektronik yang sudah terhubung dengan alat tersebut.

\section{1) Sistem Usulan}

Use Case diagram pada gambar 4.2 menjelaskan fungsi dari user pada sistem atau aplikasi ini. Dalam sistem yang akan dibuat, hanya terdapat satu aktor yang berperan sebagai pengguna system dan terdapat satu use case untuk menggambarkan fungsionalitas sistem. Aktor harus masuk keprogram aplikasi lalu memulai suatu program dan memerintahkan untuk menghidup atau mematikan suatu alat elektronik dan selesai menggunakan aplikasi actor stop aplikasi program tersebut serta keluar dari aplikasinya.

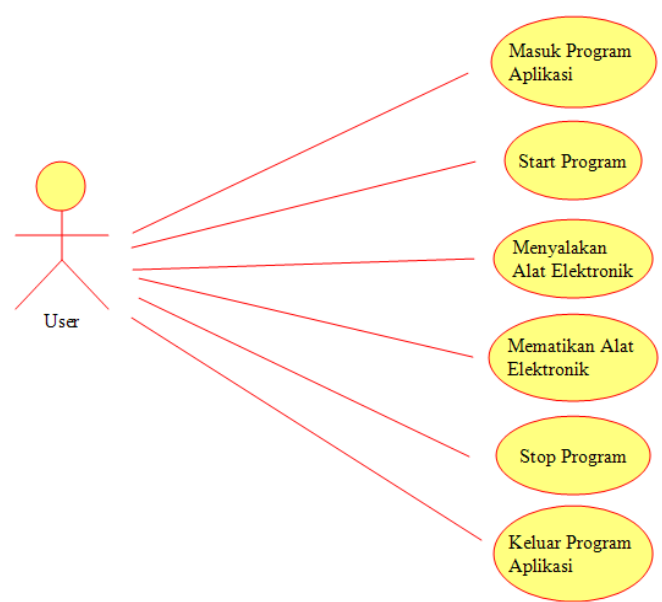

Gambar 4. Use Case Diagram Sistem Secara Umum

\section{2) Perancangan Perangkat}

Pada tahap perancangan sistem, developer merupakan prototype sesuai dengan requirment yang telah dilakukan dan dianalisis pada tahapan sebelumnya. Prototype yang dibangun dari awal karena belum ada prototype sebelumnya yang dirancang di SMK XYZ . Dalam tahap perancangan prototype ini dilakukan perancangan modul Mikrokontroller atmega8. Rancangan yang cepat ini akan membawa ke arah pembuatan program (kontruksi) dari prototype.

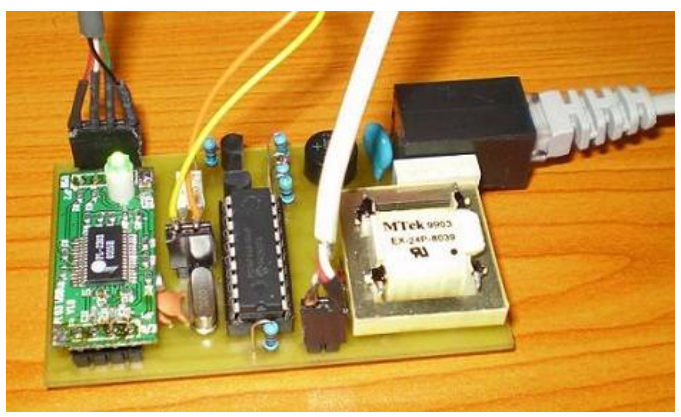

Gambar 5. Modul Mikrokontroller Atmega8 


\section{3) Perancangan Software Pada Mikrokontroller}

Perancangan software pada mikrokontroler bertujuan untuk mengetahui mikrokontroler ATmega8, sebagai jantung pengolahan data, yaitu proses pengiriman data ke port-port meneruskan ke alat elektronik menggunakan BASCOM AVR 1.11.9.0 sebagai editor text nya.

4) Perancangan Hardware pada Mikrokontroller AVR ATmega $8 L 8 A U$

Perancangan hardware pada mikrokontroler bertujuan untuk mengetahui mikrokontroler ATmega8L8AlU, sebagai pengontrolan alat elektronik. Speksifikasi sebagai berikut :

- Memiliki in-sistem programming untuk IC yang mendukung, dilengkapi led programming indicator.

- Memiliki 28 pin jalur input/output.

- Lengkap dengan osilator $8 \mathrm{MHZ}$

- Lengkap dengan rangkaian reset, tombol manual reset dan brown output detector.

- Menggunakan tegangan input $5 \mathrm{Vdc}$ dan memiliki tegangan output $5 \mathrm{Vdc}$.

Dari diagram block pada gambar 4.5 tampak bahwa pemprograman mikrokontroller terdiri dari beberapa bagian. Bagian-bagian tersebut yaitu : inisialisai hardware, inisialisasi ini meliputi :

- Jenis mikro, Berisi nama register file yang digunakan.

- Frekuensi Kristal .Berisi konstanta angka frekuensi pada Kristal yang digunakan.

- Baund Rate, berisi konstanta angka baund rate yang digunakan.

Hardware stack. Berisi angka tentang ruang yang tersedia untuk memanggil routine dalam bahasa mesin pada perangkat keras.

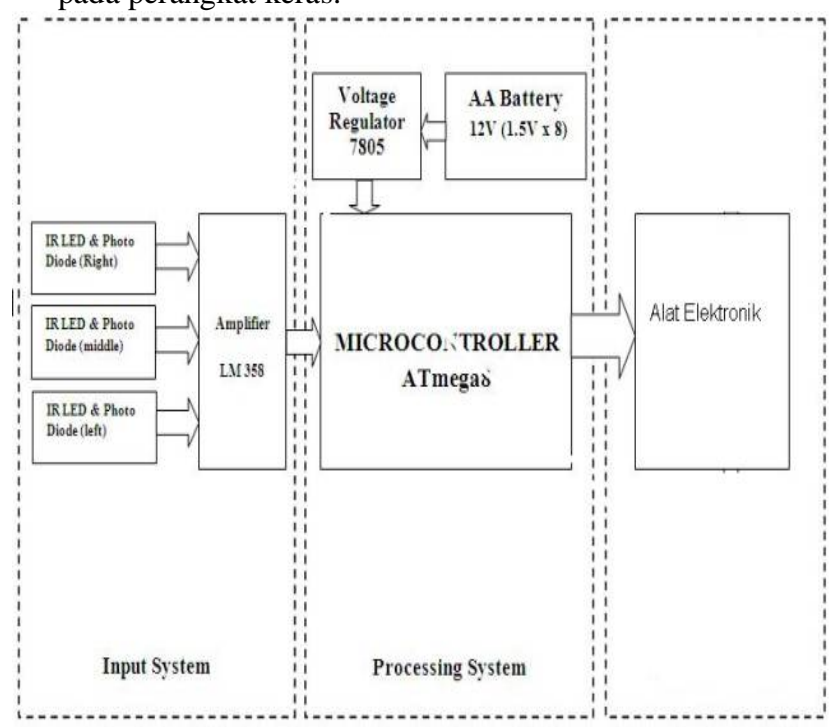

Gambar 6. Diagram Block Sistem Kerja Mikrokontroller

\section{Implementasi}

Tujuan Implementasi adalah untuk menerapakan perancangan yang telah dilakukan terhadap sistem sehingga user dapat memberikan masukan untuk perbaikan sistem yang telah dibangun. Perangkat keras dan perangkat lunak yang digunakan untuk melakukan implementasi dan pengujian sistem yang akan melalui proses sebagai berikut :

\section{1) Cara Kerja Sistem}

Cara kerja sistem kontrol alat elektronik dengan Visual Basic 2010, yaitu :

- Software Visual Basic 2010 dihubungkan dengan device controller

- Kemudian menjalankannya dari aplikasi yang terhubung ke device controller.

- Kemudian port serial mentranfer perintah dari aplikasi ke device controller dan device controller yang terhubung dengan alat elektronik akan mentransfer perintah tersebut ke alat elektronik.

- Sinyal dari laptop/pc lewat port serial diteruskan kerangkaian device controller dalam bentuk sinyal digital.

- Sinyal digital dari mikrokontroler mengontrol alat elektronik yang sudah terhubung kedalam device controller berdasarkan input sinyal yang diberikan pada sistem kontrol alat elektronik.

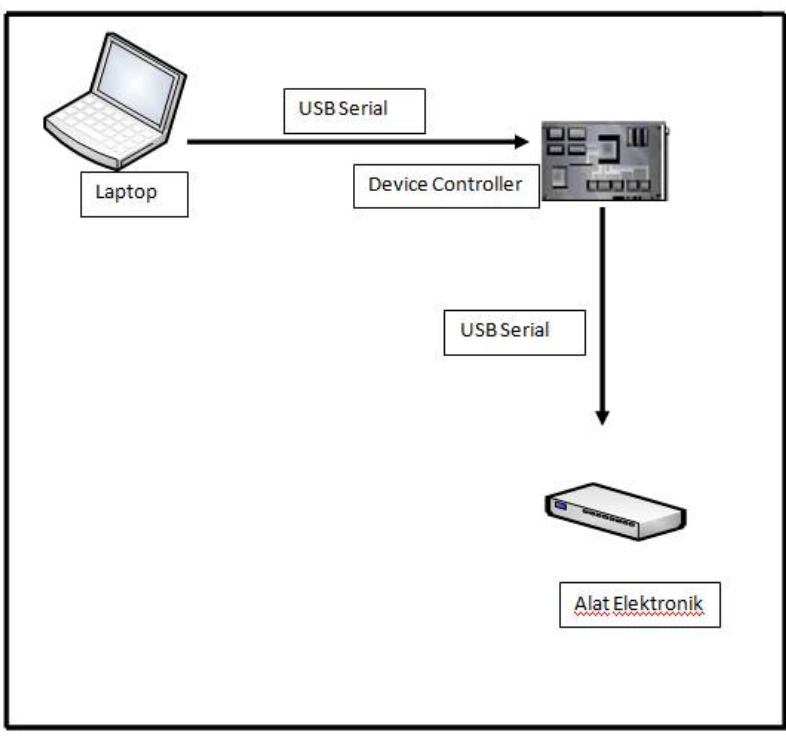

Gambar 7. Skema Kerja

Gambar 4.6 merupakan skema cara kerja system dalam melakukan pengiriman perintah dan menerima perintah dari program aplikasi yang di jalankan oleh user melalui USB Serial, kemudian diteruskan kerangkaian device controller yang merupakan mikrokontroler untuk mengendalikan alat elektronik. Port komputer yang dipakai adalah port serial sebagai penghubung ke device 
controller. Selanjutnya dari device controller mengirim perintah ke alat elektronik on/off.

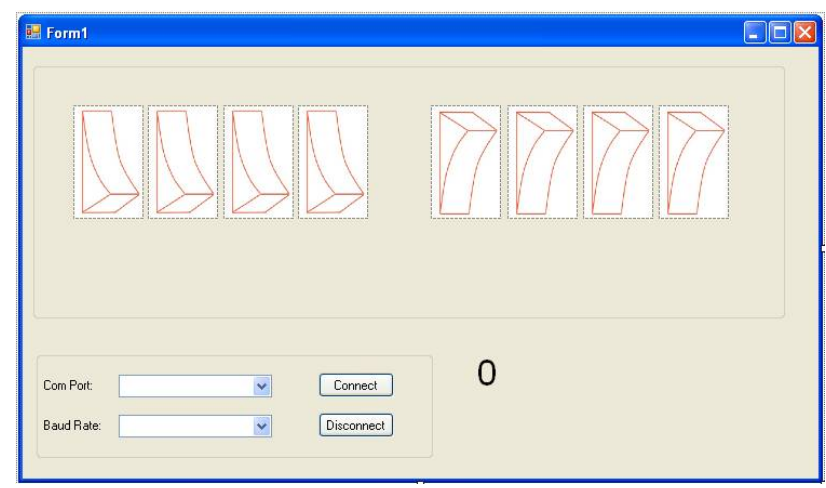

Gambar 8. Tampilan Aplikasi

\section{2) Cara Kerja Hardware}

Adapun cara kerja hardware control ini sangat sederhana. Pada saat port-port parallel memberikan perintah " 1 ", secara otomatis kaki basis akan mendapatkan arus. Karena ada arus pada kaki basis transistor maka kondisi transistor berada pada titik kerja kondisi ini dapat disamakan dengan sakelar tertutup atau On. Keadaan ini akan menyebabkan arus yang melewati relay teralirkan dapat mengaktifkan relay. Sebaliknya jika port paraler memeberikan input logika "0", maka tidak ada arus basis. Hal ini mendakan posisi Off.

\section{Pengujian Sistem}

Setelah melakukan pembuatan program aplikasi, maka tahap berikutnya adalah melakukan pengujian. Pengujian system akan membahasan kontro alat elektronik melalui Visual Basic 2010 yang hanya dilakukan oleh pihak SMK XYZ yang memiliki hak penuh untuk menggunakan Program aplikasi dan pengontrolan alat elektronik.

Untuk melakukan pengontrolan alat elektronik tersebut, User harus masuk ke program aplikasi prototype pengontrolan alat elektronik agar dapat memberi perintah on/off pada alat elektronik di SMK XYZ.

Objek yang digunakan untuk melakukan pengujian yaitu berupa TV, Kipas Angin, mesin air, mesin foto copy, Ampli, Kulkas, Infocus, dan monitor sound. Rangkaian device controller yang digunakan untuk pengujian telah dimodifikasi sedemikian rupa menggunakan adabtor, lampu LED, dan mikrokontroler. Pengujiannya adalah sebagai berikut.

1) Menyalakan Alat Elektronik dengan Visual Basic 2010

Pengujian ini dilakukan dengan cara user mengklik

saklar on pada program aplikasi prototype pengontrol alat elektronik. Misalnya ingin menyalakan port 1 yang diisi nama "Kipas Angin". Kemudian system akan menjalankan perintah on mengirimkan ke device controller kemudian meneruskan ke alat elektronik. Bukti menunjukkan bahwa alat elektronik tersebut dalam keadaan "on" adalah dapat dilihat di program aplikasi dan lampu yang ada di device controller.

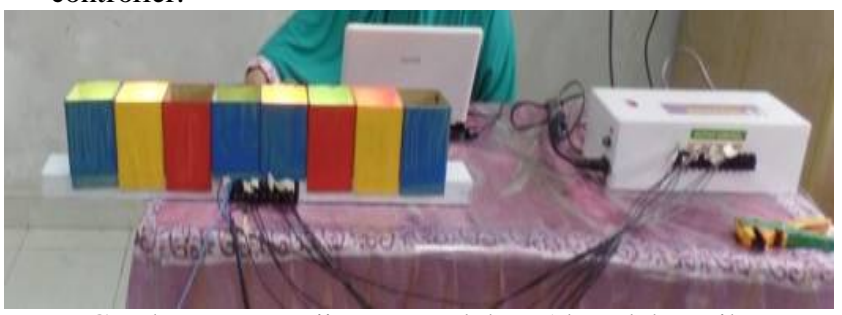

Gambar 9. Pengujian Menyalakan Alat Elektronik

2) Mematikan Alat Elektronik dengan Visual Basic 2010

Pengujian ini dilakukan dengan cara user mengklik saklar off pada program aplikasi prototype pengontrol alat elektronik. Misalnya ingin menyalakan port 7 yang diisi nama "Infocus". Kemudian system akan menjalankan perintah off mengirimkan ke device controller kemudian meneruskan ke alat elektronik. Bukti menunjukkan bahwa alat elektronik tersebut dalam keadaan "off" adalah dapat dilihat di program aplikasi dan lampu yang ada di device controller.

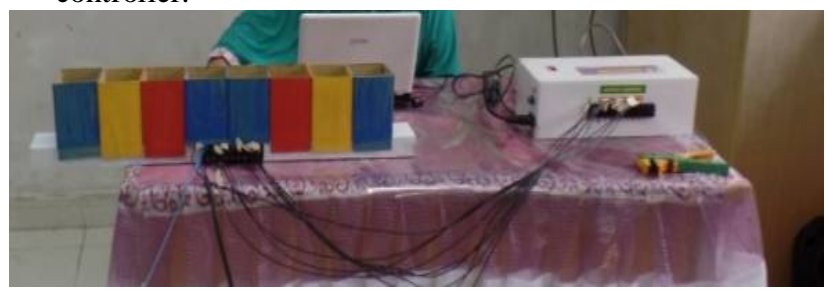

Gambar 10. Pengujian Mematikan Alat Elektronik

3) Uji Software

Sebelum masuk ke dalam penjelasan tentang tahap pengujian akan digambarkan terlebih dahulu rangakaian metode pengujian yang dilakukan untuk memberikan pandangan tentang cara pengujian yang diterapkan. Pengujian program aplikasi yang telah dibuat dilakukan dengan metode black-box testing . Menggunakan metode black-box testing memungkinkan developer untuk membuat himpunan kondisi input yang akan melatih seluruh syarat-syarat fungsional suatu program. Walau didesain untuk menemukan kesalahan, uji coba black-box digunakan untuk mendemonstrasikan fungsi aplikasi yang dioperasikan. Tujuan dari pengujian ini adalah membuktikan bahwa hasil output sesuai seperti yang diharapkan. Berikut hasil pengujian yang dilakukan developer dari sistem pengontrol alat elektronik SMK XYZ jarak jauh visual basic 2010 dengan menggunakan black-box testing untuk mengetahui apakah cara berinteraksi pengguna di dalam rancangan interface ( antar muka ) User dengan program aplikasi serta rangkaian device controller di dalam aplikasi sudah berjalan dengan semestinya. 
Tabel 1. Blackbox Testing

\begin{tabular}{|l|c|l|}
\hline \multicolumn{1}{|c|}{ Pengujian } & Valid & \multicolumn{1}{c|}{ Invalid } \\
\hline Interface & $\checkmark$ & - \\
\hline Program Aplikasi & $\checkmark$ & - \\
\hline Device Controller & $\checkmark$ & - \\
\hline
\end{tabular}

Hasil pengujian Interface ( antar muka) yang tertulis pada tabel 4.3 menjelaskan bahwa di dalam pengujian antar muka system mendapatkan hasil valid karena system dapat di gunakan oleh user tanpa adanya error. Kemudian pengujian program aplikasi juga valid. Selanjutnya hasil pengujian pada rangkaian device controller yang dihubungkan dengan alat elektronik menunjukkan bahwa hasilnya valid, karena rangkaian mampu bekerja dengan aplikasi yang dapat digunakan untuk aktivitas pengontrolan alat elektronik.

Apabila aplikasi benar-benar valid akan diakadakan pengujian dengan melakukan terting kepada tester. Tester disini adalah warga sekolah atau kepala sekolah yang bertanggung jawab atas alat-alat elektronik disekolah tersebut yang akan di kontrol dengan aplikasi ini. Pengujian yang dilakukan meliputi pengujian untuk menyalakan alat elektronik, mematikan alat elektronik.

\section{4) Hasil Pengujian Menyalakan Alat Elektronik}

\begin{tabular}{|l|l|l|l|l|}
\hline \multicolumn{5}{|c|}{ Tabel 4.4 Black Box Menyalakan Alat Elektronik } \\
\hline Kode & Item Nama Pengujian & Hasil yang Diharapkan & Hasil Uji & Kebenaran \\
\hline L1 & TV & TV Menvala & TV Menvala & Benar \\
\hline L2 & Kipas Angin & Kipas Angin Menvala & Kipas Angin Menvala & Benar \\
\hline L3 & Infocus Proyektor & Infocus Menvala & Infocus Menvala & Benar \\
\hline L4 & Mesin Air & Mesin Air Menvala & Mesin Air Menvala & Benar \\
\hline L5 & Ampli & Ampli Menvala & Ampli Menvala & Benar \\
\hline L6 & Mesin Foto copy & Mesin Foto copy & Mesin Foto copy & Benar \\
\hline & & Menvala & Menvala & \\
\hline L7 & Kulkas & Kulkas Menvala & Kulkas Menvala & Benar \\
\hline L8 & Monitor sound & Monitor Sound Menvala & Monitor Sound Menvala & Benar \\
\hline I & & &
\end{tabular}

\section{5) Hasil Pengujian Mematikan Alat Elektronik}

\begin{tabular}{|c|c|c|c|c|}
\hline \multirow{2}{*}{ Kode } & \multicolumn{4}{|c|}{ Tabel 4.5 Black Box Mematikan Alat Elektronik } \\
\hline & Item Nama Penguijan & Hasil yang Diharapkan & Hasil Uji & Kejenaran \\
\hline L1 & TV & TV Mati & TV Mati & Benar \\
\hline L2 & Kipas Angin & Kipas Angin Mati & Kipas Angin Mati & Beiar \\
\hline L3 & Infocus Proyektor & Infocus Mati & Infocus Mati & Benar \\
\hline L4 & Mesin Air & Mesin Air Mati & Mesin Air Mati & Beiar \\
\hline L5 & Ampli & Ampli Mati & Ampli Mati & Benar \\
\hline L6 & Mesin Foto copy & Mesin Foto copy Mati & Mesin Foto copy Mati & Benar \\
\hline L7 & Kullkas & Kullkas Mati & Kulkas Mati & Benar \\
\hline L8 & Monitor sound & Monitor Sound Mati & Monitor Sound Mati & Benar \\
\hline
\end{tabular}

\section{Penutup}

\section{A. Kesimpulan}

Berdasarkan hasil pembahasan dan pengujian yang telah dilakukan, maka dapat diambil kesimpulan bahwa Prototype pengontrol Alat Elektronik di SMK XYZ jarak jauh menggunakan Visual Basic 2010 dapat di hubungkan dengan Device Controller yang terhubung dengan alat elektronik dan dapat mengontrol secara jarak jauh. Dari pengujian yang telah dilakukan, sistem berhasil menyalakan dan mematikan alat elektronik ( Televisi, Kipas Angin, Mesin Air, Mesin fotocopy, Infocus, Kulkas, Ampli, dan Monitor Sound).

\section{B. Saran}

Saran yang dapat diberikan untuk penijauan dan pengembangan lebih lanjut dari Prototype pengontrol alat elektronik yaitu dapat di kembangkan menggunakan perintah modem pengiriman pesan ke User bahwa sistem dalam gangguan menggunakan Handphone berbasis SMS

\section{DAFTAR PUSTAKA}

[1] A. S. , Rosa dan M. Shalahuddin. 2013. Rekayasa Perangkat Lunak Terstruktur dan Berorientasi Objek. Informatika. Bandung.

[2] Atmel Corporation, (2015), ATmega8, diakses pada 9 Maret 2015, << http://www.engineernusantara.ga/2015/03/pengenalan-mikrokontrolleravr-atmel.html

[3] Kusrianto, Adi. 2005. Panduan Lengkap Memakai Microsoft Office Project 2003. PT Elex Media Komputindo. Jakarta.

[4] Kusuf Weldan, (2013), Teknik Pemprograman, Malang : PPPPTK BOE.

[5] Lethbridge, Timothy C, Laganiere, Robert, 2002, Object-Oriented Software Engineering. McgrawHill, United Kingdom

[6] Metode Pengembangan, (2015), Pengembangan Software Metode $\begin{array}{lllll}\text { Prototype, diakses } & \text { pada } 13 & \text { Maret } & \end{array}$ > >http://www.etunas.com/web/>> 